\title{
Feasibility of subcutaneous antibiotics for palliative care patients
}

\author{
Raquel Gallardo ${ }^{1}$ and Fernando Miguel Gamboa ${ }^{2 *}$ \\ ${ }^{1}$ Department of Pharmacy, Nuestra Senora de Valme University Hospital, Seville, Spain \\ ${ }^{2}$ Department of Internal Medicine, Nuestra Senora de Valme University Hospital, Seville, Spain
}

\begin{abstract}
Aim
We conducted a narrative review of the literature to better understand the use of subcutaneous administration, especially in palliative care patients with an infection. The aim of this review is to determine the feasibility of using subcutaneous antibiotics in palliative care patients. No ethical approval was needed.
\end{abstract}

\section{Introduction}

The number of patients requiring palliative care is increasing every day due to population ageing and the increase in degenerative and chronic diseases [1]. These patients can be particularly vulnerable to infection due to immune dysfunction, especially after chemotherapy regimens in those with cancer, or as a result of multiple comorbid conditions and complex diseases [2-5]. One third of terminally ill patients develop infections during their final phase of care [4]. The percentage of patients using antibiotics in hospice care ranges from $36 \%$ to $84 \%$ [5-6]. Antibiotic therapy for the management of neutropenia and non-neutropenic haematologic diseases has been widely described and is regularly updated. However, there is little information regarding the management of antibiotic therapy in palliative care patients [4-7].

Using antibiotics in palliative care patients is complex. As palliative care focuses on relieving and preventing suffering and improving quality of life, treatment choices should be made based on symptom improvement and control. Antibiotic treatment might be considered part of a good palliative care plan in the presence of life-threatening infections, but the decision to treat can also lead to burdens due to diagnostic tests, adverse reactions to antibiotics or the use of intravenous lines [7]. Other aspects, such as patient and family wishes, the patient's overall condition and prognosis, and the potential for symptom control, must also be considered [3,7-8].

In palliative care the oral route of administration is advocated as the first choice for the treatment of symptoms [1,6-7]. However, there are certain situations where this is impossible (gastric intolerance, swallowing disorders, persistent nausea and vomiting, intolerance to oral administration of opioids, malabsorption, extreme weakness, delirium, severe pain) and an alternative route is required [9]. In these situations, intravenous, rectal, intramuscular, sublingual and transdermal routes are alternatives to oral administration, but they all have their disadvantages. In the case of intravenous administration, the need for qualified personnel, difficulty of administration at home, frequent infections and other limitations such as less patient autonomy and high cost are the main drawbacks [10]. Rectal administration is a low-cost alternative, but there are only a few drugs that may be used this way and none of them are antibiotics. Moreover, absorption and bioavailability are variable and not predictable [11]. The main downside of intramuscular administration is pain [12]. Patients with low levels of muscular mass (cachexia) also restrict the usefulness of this route [13]. There are no antibiotics available that can be administered sublingually $[13,14]$. Transdermal administration can also be a good alternative, but the delay (12-24 hours) before reaching the steady state plasma concentration makes it difficult to control symptoms in the first 72 hours. It also has long-lasting effects after it is withdrawn and high individual variability.

Between $53-70 \%$ of terminal cancer patients require an alternative route of drug administration $[13,15,16]$. Subcutaneous administration is an alternative in those situations where the oral, intravenous or intramuscular routes are not suitable in palliative care patients [16].

\section{The subcutaneous route: advantages and disadvantages}

The subcutaneous tissue is located below the dermis. The amount of subcutaneous tissue varies from person to person and decreases with disease progression. There are no significant barriers to absorption. Medications delivered subcutaneously easily enter the bloodstream by passing through the spaces between cells of the capillary wall. They enter the bloodstream by a combination of perfusion, diffusion, hydrostatic pressure and osmotic pressure. There is therefore no firstpass metabolism by the liver, in contrast with the oral route [17].

The subcutaneous route of administration is widely used in palliative treatment $(60 \%$ of palliative care patients will need the subcutaneous route) $[16,17]$. The subcutaneous route is a safe, low-cost and effective option for drug administration $[17,18]$.

There are currently no firm recommendations on subcutaneous administration of antibiotics and few studies regarding their use in the treatment of infection in palliative care patients.

\section{Method}

\section{Search strategies and data sources}

We searched various bibliographic databases: PubMed, the Cochrane Library, the Cumulative Index to Nursing and Allied Health Literature (CINAHL), EMBASE and Trip Database.

Correspondence to: Fernando Miguel Gamboa, Nuestra Senora de Valme University Hospital, Seville, Spain, E-mail: fernandom.gamboa.sspa@ juntadeandalucia.es

Received: February 02, 2017; Accepted: February 22, 2017; Published: February 25,2017 
Initially, the search focused on papers on palliative care and subcutaneous drug administration. For this first search strategy, we used the following MeSH headings: injection subcutaneous, infusions subcutaneous, palliative care, terminally ill, as well as free text words included in the article titles or abstracts. We selected the papers most relevant to our topic and reviewed their keywords and bibliography to find other articles of interest. Secondly, we performed another search for studies on subcutaneous administration of antibiotics, including those performed in volunteers and in critically ill patients. Here we included the following MeSH headings: amoxicillin, cefotaxime, ceftazidime, ceftriaxone, ciprofloxacin, clarithromycin, clindamycin, fluconazole, imipenem or cilastatin imipenem drug combination, levofloxacin, metronidazole, teicoplanin, tobramycin and anti-bacterial agents. We also performed a manual search of references of interest identified in the different studies.

\section{Inclusion and exclusion criteria}

Our search included English, Spanish and French-language literature. The search focused on studies performed in humans over the course of 12 years (2000-2012). All types of research design were considered: original articles, letters to the editor, conference papers, clinical practice guidelines, reviews and other studies on subcutaneous administration as an alternative route in palliative care.

We excluded studies on subcutaneous administration in children and studies in animals. We reviewed the bibliographies of all the publications found to look for other articles of interest.

\section{Results}

We found 55 relevant papers using the first search strategy. These included original articles, letters to the editor, case reports, drug mixture compatibility studies and pharmacokinetic studies. The data provided came from clinical trials and review articles in just a few cases.

Patient age ranged from 17 to 84 years old, terminally ill cancer patients. Most of the studies were performed in Europe and the United States. These studies were conducted in hospitals, hospices or private homes. There were also several compatibility studies. Sample size ranged from 2 to 60 in studies on subcutaneous drug administration. Length of subcutaneous treatment was 4 to 21 days.

Most of the studies had shortcomings in their method due to small sample group size, differences in comparative groups and no randomisation. In the end, we selected 10 articles on the use of subcutaneous antibiotics ( 5 in healthy volunteers and 5 in patients with infections). A descriptive review of the results of the 10 studies selected is provided below.

\section{Use of subcutaneous antibiotics}

As many antibiotics are approved for intramuscular administration and a high percentage of intramuscular injections (85-95\%) are actually administered into subcutaneous fat, the subcutaneous route can be proposed as an alternative in palliative care [19-21]. Most of the studies on subcutaneous administration of antibiotics are case reports, or their aim is to evaluate the pharmacokinetics of the drug administered subcutaneously but neither the efficacy nor the safety have been determined [15]. A summary of the evidence found in the literature is provided in (Tables 1-2).

\section{Ceftriaxone}

We found 5 studies on the subcutaneous administration of ceftriaxone. All of them had a small sample size, between 4 and 44 patients, and compared the pharmacokinetics of the drug administered subcutaneously vs. intravenously. In 1 study, the subcutaneous route was used in palliative patients when the patient refused intravenous administration or venous access was difficult [22]. The doses reported ranged from $0.5 \mathrm{~g}$ to $2 \mathrm{~g}$, administered over a period of 10-12 minutes. The maximum number of days of subcutaneous treatment reported was 10 .

All of the studies conclude that ceftriaxone can be administered subcutaneously to palliative care patients because of the similar plasma concentrations reported when comparing the pharmacokinetics of subcutaneous and intravenous administration. The area under the curve (AUC) was considered similar in all the studies [15, 22-26].

The studies report several local adverse effects, such as induration, bleeding or pain [15, 22-23]. Only 1 study reports a severe adverse effect: subcutaneous necrosis with slow healing [24].

Subcutaneous ceftriaxone administration is approved in France. The ceftriaxone monograph recommends a dose of 1 to $2 \mathrm{~g}$ per day dissolved in water for injection (WFI), $0.9 \%$ saline solution (SS), or $5 \%$ glucose solution (GS). In a bolus administration the amount of

Table 1. Summary of the evidence on subcutaneous antibiotic administration.

\begin{tabular}{|c|c|c|c|c|}
\hline $\begin{array}{l}\text { Author } \\
\text { Year }\end{array}$ & $\begin{array}{c}\mathrm{N} \\
\text { Inclusion criteria }\end{array}$ & Objectives & Design & Conclusions \\
\hline \multicolumn{5}{|c|}{ CEFTRIAXONE } \\
\hline $\begin{array}{l}\text { Borner et al. } \\
1985\end{array}$ & $\begin{array}{c}\mathrm{N}=10 \\
\text { Age: } 22-43 \\
\text { Healthy volunteers }\end{array}$ & PK and tolerability & $\begin{aligned} 2 \mathrm{~g} \mathrm{IV} \text { ceftriaxone. Randomised to: } \\
$\[ \quad 0.5 \mathrm{~g} \mathrm{SC}+\text { lidocaine } \]$ \\
-\quad 0.5 \mathrm{~g} \mathrm{IV}\end{aligned}$ & $\begin{array}{c}\text { Similar PK } \\
\text { Well tolerated } \\
\mathrm{AUC}_{\mathrm{SC}}=\mathrm{AUC}_{\mathrm{IV}}\end{array}$ \\
\hline $\begin{array}{c}\text { Lacut et al. } \\
1986\end{array}$ & $\begin{array}{c}\mathrm{N}=30 \\
\text { Age: } 17-84 \\
\text { Severe infection }\end{array}$ & PK of IV, IM and SC & $\begin{array}{l}\text { Alone or combined }(50 \%) \\
\bullet \quad 1-3 \mathrm{~g} / \text { day } \\
\text { Days: } 17(10-62)\end{array}$ & Similar PK \\
\hline $\begin{array}{l}\text { Bricaire et al. } \\
1988\end{array}$ & $\begin{array}{l}\mathrm{N}=4 \\
\text { Healthy volunteers } \\
\quad \mathrm{N}=8 \\
\text { Urinary infection }\end{array}$ & PK of SC and IV & $\begin{array}{ll}\mathrm{N}=4 \\
\stackrel{\mathrm{N}=8}{\bullet} & \text { Single dose } 2 \mathrm{~g} \mathrm{SC} \\
\bullet & 2 \mathrm{~g} \mathrm{IV}(3 \text { days }) \text { followed by } 2 \mathrm{~g} \mathrm{SC} \text { ( } 3 \text { days })\end{array}$ & $\begin{array}{l}\text { Similar PK } \\
\text { Local effects } \\
\text { SC necrosis }\end{array}$ \\
\hline $\begin{array}{l}\text { Melin-Coviaux } \\
\text { et al. } \\
2000\end{array}$ & $\begin{array}{c}\mathrm{N}=26 \\
\text { Elderly } \\
\text { Infections }\end{array}$ & PK of SC and IV & $\begin{array}{cc}\bullet & 1 \mathrm{~g} \mathrm{IV} \\
\bullet & 1 \mathrm{~g} \mathrm{SC} \\
\text { Days: } 7 & \end{array}$ & Similar PK \\
\hline $\begin{array}{l}\text { Centeno et al. } \\
2008\end{array}$ & $\begin{array}{c}\mathrm{N}=44 \\
\text { Palliative } \\
\text { Respiratory infection }\end{array}$ & Prospective study & $\begin{array}{l}\bullet 1-2 \mathrm{~g} \mathrm{SC} \text { (with lidocaine) } \\
\text { Days: } 1-10\end{array}$ & $\begin{array}{l}\text { Verbal numerical scale: } 0-1 / 10 \\
\text { Site reactions }\end{array}$ \\
\hline
\end{tabular}

PK: pharmacokinetics, IV: intravenous, SC: subcutaneous, AUC: area under the curve, IM: intramuscular. 
Table 2: Summary of the evidence on subcutaneous antibiotic administration (PK: pharmacokinetics, IV: intravenous, SC: subcutaneous, AUC: area under the curve, IM: intramuscular, Bv: bioavailability).

\begin{tabular}{|c|c|c|c|c|}
\hline Author Year & $\begin{array}{c}\mathrm{N} \\
\text { Inclusion criteria }\end{array}$ & Objectives & Design & Conclusions \\
\hline \multicolumn{5}{|c|}{ CEFEPIME } \\
\hline $\begin{array}{l}\text { Walker et al. } \\
2005\end{array}$ & $\begin{array}{l}\mathrm{N}=10 \\
\text { Healthy volunteers } \\
\text { Age: } 27(22-45)\end{array}$ & PK and tolerability & $\begin{array}{l}\bullet 1 \mathrm{~g} \mathrm{SC} \\
\text { Single dose }\end{array}$ & $\begin{array}{l}\text { Similar PK to IM administration } \\
\text { Local adverse effects at injection site }\end{array}$ \\
\hline \multicolumn{5}{|c|}{ TOBRAMYCIN/AMPICILLIN } \\
\hline $\begin{array}{l}\text { Champoux et al. } \\
1996\end{array}$ & $\begin{array}{l}\mathrm{N}=42 \\
\text { Healthy volunteers } \\
\text { Age: }<50 \text { and }>65\end{array}$ & Cross-over design & 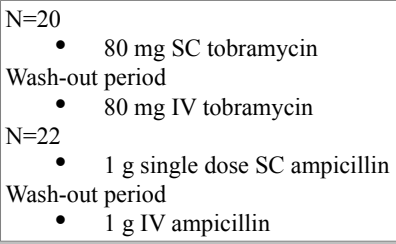 & $\begin{array}{c}\text { Similar PK } \\
\text { (similar AUC) } \\
\text { Well tolerated }\end{array}$ \\
\hline \multicolumn{5}{|c|}{ AMIKACINE } \\
\hline $\begin{array}{l}\text { Leng et al. } \\
1979\end{array}$ & $\begin{array}{c}\mathrm{N}=5 \\
\text { Healthy volunteers } \\
\text { Age: } 20-45\end{array}$ & $\begin{array}{c}\text { PK } \\
\text { IV, IM and SC }\end{array}$ & $\begin{array}{l}\quad \bullet \quad 7.5 \mathrm{mg} / \mathrm{Kg} / \text { day } \\
\text { IV, IM and SC } \\
\text { Every } 3 \text { days }\end{array}$ & $\begin{array}{c}\mathrm{T}_{\operatorname{max~SC}} \text { amikacin }>\text { than } \mathrm{T}_{\operatorname{max~IV}} \text { amikacin } \\
\mathrm{Bv}_{\mathrm{SC}}: 54 \%\end{array}$ \\
\hline \multicolumn{5}{|c|}{ TEICOPLANIN } \\
\hline $\begin{array}{l}\text { Barbot et al. } \\
2003\end{array}$ & $\begin{array}{l}\mathrm{N}=12 \\
\text { Infections }\end{array}$ & Cross-over design & $\begin{array}{l}\text { Loading dose: } \\
\bullet \quad 6 \mathrm{mg} / \mathrm{Kg} / 12 \mathrm{~h}(2 \text { days }) \\
\text { Randomised IV/SC maintenance dose: } \\
\bullet \quad 6 \mathrm{mg} / \mathrm{Kg} / \text { day }\end{array}$ & Similar PK \\
\hline \multicolumn{5}{|c|}{ ERTAPENEM } \\
\hline $\begin{array}{l}\text { Frasca et al. } \\
2010\end{array}$ & $\begin{array}{l}\mathrm{N}=6 \\
\text { Age: } 56 \pm 19 \\
\text { Infection }\end{array}$ & PK and tolerability & $\begin{array}{ll}- & 1 \mathrm{~g} / \text { day } \\
- & \mathrm{SC} \text { or IV }\end{array}$ & $\begin{array}{c}\text { Similar PK } \\
\text { Local adverse effects }\end{array}$ \\
\hline
\end{tabular}

dissolvent recommended is $3.5 \mathrm{~mL}$; for continuous infusion, $20 \mathrm{~mL}$ is recommended. Time for administration should be between 15 and 30 minutes [25-27].

\section{Cefepime}

This antibiotic is approved for intravenous and intramuscular use [28]. A study of 10 healthy volunteers, of a mean age of 27 years, compared subcutaneous vs. intramuscular cefepime administration, and found similar plasma concentrations. Subcutaneous administration was well tolerated. Mild local side effects were reported (pain, swelling and erythema). The dose administered was $1 \mathrm{~g}$ diluted in $50 \mathrm{~mL} \mathrm{5 \%}$ GS over 30 minutes. In this study, patients were assessed for global acceptability of the technique and the mean value was "strongly agreeable" $[15,20]$.

\section{Tobramycin}

In a cross-over study of 20 healthy volunteers, $80 \mathrm{mg}$ tobramycin diluted in $50 \mathrm{~mL} 0.9 \%$ SS was administered subcutaneously over 20 minutes or intravenously over 30 minutes and similar AUCs were found [29].

\section{Amikacin}

In a case report of an 85-year-old patient with urine infection, 15 $\mathrm{mg} / \mathrm{Kg} /$ day amikacin was administered subcutaneously in combination with ampicillin. Skin necrosis was reported as an adverse effect [30].

In a comparative, non-randomised, pharmacokinetic study with 5 healthy volunteers aged 20 to $45,3 \mathrm{mg} / \mathrm{Kg}$ /day amikacin was administered intravenously over 3 days followed by $7.5 \mathrm{mg} / \mathrm{Kg} /$ day intramuscular amikacin over 3 days, and finally $7.5 \mathrm{mg} / \mathrm{Kg} /$ day subcutaneous amikacin over 3 days. The authors concluded that subcutaneous administration of amikacin has a longer $\mathrm{T}_{\max }$ (time to reach $\mathrm{C}_{\max }$ ) than intravenous administration, and amikacin bioavailability was $54 \%$ [30].

Subcutaneous administration of amikacin is approved in France [31]. The amikacin monograph recommends a dose of $15 \mathrm{mg} / \mathrm{Kg} /$ day in patients with normal renal function. The $50 \mathrm{mg}$ intravenous presentation must be dissolved in $1 \mathrm{~mL}$ WFI before subcutaneous administration. Doses must be adjusted in patients with renal failure [32].

\section{Ampicillin}

In a study of 22 healthy volunteers, $1 \mathrm{~g}$ ampicillin diluted in 50 $\mathrm{mL} 0.9 \%$ SS was administered subcutaneously over 20 minutes and compared with the same solution administered intravenously over 30 minutes. A delay in the time it took to reach peak plasma concentration was reported but the AUC was similar [29].

\section{Teicoplanin}

A maintenance dose of $6 \mathrm{mg} / \mathrm{Kg} /$ day of intravenous teicoplanin was compared with the same dose administered subcutaneously [33]. The study reported a higher subcutaneous $\mathrm{C}_{\text {max }}$ (the peak plasma concentration of a drug after administration) but it took longer to achieve compared with intravenous administration. The reported AUC was similar in both groups [33].

\section{Ertapenem}

In a pharmacokinetic study in 6 patients with infection, intravenous administration of $1 \mathrm{~g}$ ertapenem diluted in $50 \mathrm{~mL} 0.9 \% \mathrm{SS}$ over 30 minutes was compared with subcutaneous administration of the same. Peaks were reduced with subcutaneous administration $\left(\mathrm{C}_{\max }\right.$ $\left.{ }_{\mathrm{IV}}>\mathrm{C}_{\operatorname{max~SC}}\right)$, and time to maximum concentration was delayed $\left(\mathrm{T}_{\max }\right.$ $\left.{ }_{\mathrm{IV}}<\mathrm{T}_{\operatorname{max~SC}}\right)$. However, the AUC was similar $\left(\mathrm{AUC}_{0-24 \mathrm{~h} \mathrm{SC}} / \mathrm{AUC}_{0-24 \mathrm{IV}}=0.99\right.$ 
\pm 0.18 ) after both routes of administration, and confirmed by complete bioavailability following the subcutaneous infusion.

Ertapenem antimicrobial activity is considered to be time dependent, so a peak reduction after subcutaneous administration may not have important consequences on efficacy. Therefore, this study suggests that subcutaneous ertapenem administration could be equivalent to the intravenous infusion [19].

\section{Other studies on subcutaneous antibiotics}

Subcutaneous administration of other antibiotics such as gentamicin, sisomicin or netilmicin has also been studied. Skin reactions have been reported after subcutaneous administration of all of these aminoglycosides [30]. Subcutaneous administration of thiamphenicol is approved in France [32].

\section{Discussion}

\section{Can the subcutaneous route be used to treat infection in palliative care patients?}

The subcutaneous route is an alternative in palliative care patients when there are problems with venous access. It is important to take into account aspects such as the patient's general condition and prognosis, as well as their preference and that of their relatives, before deciding how to treat an infection in a palliative care patient [15]. 3 antibiotics have been approved for subcutaneous administration in France: ceftriaxone, amikacin and thiamphenicol [27,32,33].

The 2 major determinants of bacteria killing include antibiotic concentration and the time that the antibiotic remains on the bacteria binding sites. The area under the serum concentration curve (AUC) after a dose of antibiotic measures how high (concentration) and how long (time) the antibiotic levels remain above the target MIC (concentration of antibiotic that is necessary to inhibit bacteria growth) during any one dosing interval. Most of the pharmacokinetic studies comparing subcutaneous administration with intramuscular or intravenous administration have found that the subcutaneous route reduces $\mathrm{C}_{\max }$. However, the AUC is similar to that of intravenous or intramuscular administration. Antibiotic effectiveness can be timedependent or concentration-dependent. Time-dependent antibiotics such as beta-lactams (penicillins, cephalosporins, carbapenems, monobactams, macrolides, glycopeptides) are effective when their serum concentration exceeds the minimum inhibitory concentration (MIC) for the microorganism. In this case, the time that antibiotic serum concentrations remain above the MIC during the dosing interval ( $t>$ MIC) is the key to effectiveness. Higher serum concentrations will not lead to higher eradication of microorganisms. In this case, reduction of $\mathrm{C}_{\max }$ when antibiotics are administered subcutaneously may not influence effectiveness because the AUCs are similar. Aminoglycosides (tobramycin, gentamycin, amikacin) are considered concentrationdependent antibiotics. Higher concentrations of antibiotics in this group means higher effectiveness, but subcutaneous administration can reduce effectiveness.

Although our findings are interesting, there are some limitations to this review. There are few articles regarding the use of subcutaneous antibiotic administration. Most of them are prospective, cross-over, short-term, small size, with healthy volunteers and their objective is to determine the pharmacokinetics of the drugs. There are not many studies that have been designed with the assessment of efficacy and safety as primary objectives. It is therefore very difficult to extrapolate these findings to larger populations.
More studies, with more robust designs, are needed to confirm the efficacy and safety of this alternative route of administration. However, research in patients near the end of life involves numerous ethical challenges: dying patients are very vulnerable, adequate informed consent may be difficult to obtain, balancing research and clinical roles is difficult, and the risks and benefits of palliative research are difficult to assess.

\section{Conclusion}

Patients requiring palliative care at the end of life may benefit from subcutaneous administration for the treatment of infection when the oral route is not possible or when venous access is difficult. Ceftriaxone, amikacin and thiamphenicol are approved in France for subcutaneous administration. Ceftriaxone, cefepime, ampicillin, amikacin, tobramycin, ertapenem and teicoplanin are time-dependent antibiotics, so effectiveness is not affected by changes in concentration when a different route of administration is used.

These 7 antibiotics can cover almost all infections caused by Gramnegative, Gram-positive, aerobic, anaerobic and extended-spectrum beta-lactamase (ESBL) microorganisms in palliative care patients. We can therefore conclude that palliative patients with infections can be treated with ceftriaxone, cefepime, ampicillin, amikacin, tobramycin, ertapenem and teicoplanin administered subcutaneously when appropriate off-label use authorisation has been obtained and a benefit assessment performed.

\section{Conflict of interest}

The authors declare no conflicts of interest.

\section{References}

1. Doyle D, Hanks G, Cherny N, Calman K (2005) Oxford Textbook of Palliative Medicine. 3rd edition. Oxford: Oxford University Press.

2. Albrecht JS, McGregor JC, Fromme EK, Bearden DT, Furuno JP (2013) A nationwide analysis of antibiotic use in hospice care in the final week of life. J Pain Symptom Manage 46: 483-490

3. White PH, Kuhlenschmidt HL, Vancura BG, Navari RM (2003) Antimicrobial use in patients with advanced cancer receiving hospice care. J Pain Symptom Manage 25: 438-443. [Crossref]

4. Vitetta L, Kenner D, Sali A (2000) Bacterial infections in terminally ill hospice patients $J$ Pain Symptom Manage 20: 326-334. [Crossref]

5. Lam PT, Chan KS, Tse CY, Leung MW (2005) Retrospective analysis of antibiotic use and survival in advanced cancer patients with infections. J Pain Symptom Manage 30: 536-543. [Crossref]

6. Pereira J, Watanabe S, Wolch G (1998) A retrospective review of the frequency of infections and patterns of antibiotic utilization on a palliative care unit. J Pain Symptom Manage 16: 374-381. [Crossref]

7. Clayton J, Fardell B, Hutton PJ, Webb D, Chye R (2003) Parenteral antibiotics in a palliative care unit: prospective analysis of current practice. Palliat Med 17: 44-48.

8. Reinbolt RE, Shenk AM, White PH, Navari RM (2005) Symptomatic treatment of infections in patients with advanced cancer receiving hospice care. J Pain Symptom Manage 30: 175-182.

9. World Health Organization (WHO). WHO Definition of Palliative Care [Internet] Geneva: WHO [cited 2013 Feb 20]. Available from: http://www.who.int/cancer/ palliative/definition/en/

10. Sociedad Española de Cuidados Paliativos (SECPAL). Guía de Cuidados Paliativos [Internet]. Madrid: SECPAL; 2010 [cited 2013 Feb 4].

11. Sociedad Espanola de Cuidados Paliativos. Historia de los cuidados paliativos en España [Internet]. Madrid: SECPAL; 2010 [cited 2013 Feb 4].

12. Barcia E, Reyes R, Luz AM, Sánchez Y, Negro S (2003) Compatibility of haloperido and hyoscine-N-butyl bromide in mixtures for subcutaneous infusion to cancer patients in palliative care. Support Care Cancer 11: 107-113. 
13. Hernández PB, López LC, García RMA (2002) Vía subcutánea: Utilidad en el control de síntomas del paciente terminal. Medifam 12: 104-110.

14. Ruíz MP, Guía clínica (2008) Usos y recomendaciones de la vía subcutánea en cuidados paliativos. Évora: Observatorio regional de cuidados paliativos de Extremadura. Junta de Extremadura. Servicio Extremeño de Salud. FundeSalud.

15. Soler Mieras A, Santaeugenia González S, Montané Esteva E (2007) [Administration of subcutaneous antibiotics in patients on palliative care]. Med Clin (Barc) 129: 236237. [Crossref]

16. Silva M, Lamelo F (2010) Utilización de la vía subcutánea en cuidados paliativos. [Internet]. La Coruña: Fisterra.com. Atención Primaria en la Red; 2013. [cited 2010 Aug 9]. Available from: http://www.fisterra.com/guias-clinicas/utilizacion-viasubcutanea-cuidados-paliativos/.

17. Justad M (2009) Continuous subcutaneous infusion: an efficacious, cost-effective analgesia alternative at the end of life. Home Healthc Nurse 27: 140-147.

18. Adam J (1997) ABC of palliative care. The last 48 hours. BMJ 315: 1600-1603. [Crossref]

19. Frasca D, Marchand S, Petitpas F, Dahyot-Fizelier C, Couet W, et al. (2010) Pharmacokinetics of ertapenem following intravenous and subcutaneous infusions in patients. Antimicrob Agents Chemother 54: 924-926. [Crossref]

20. Walker P, Neuhauser MN, Tam VH, Willey JS, Palmer JL, et al. (2005) Subcutaneous administration of cefepime. J Pain Symptom Manage 30: 170-174. [Crossref]

21. Cockshott WP, Thompson GT, Howlett LJ, Seeley ET (1982) Intramuscular or intralipomatous injections? N Engl J Med 307: 356-358. [Crossref]

22. Centeno Cortés C, Galrica Neto I, Vara Hernando F (2008) [Prospective study of subcutaneous ceftriaxone in patients on palliative care]. Med Clin (Barc) 130: 439. [Crossref]

23. Borner K, Lode H, Hampel B, Pfeuffer M, Koeppe P (1985) Comparative pharmacokinetics of ceftriaxone after subcutaneous and intravenous administration. Chemotherapy 31: 237-245.

24. Bricaire F, Castaing JL, Pocidalo JJ, Vilde JL (1988) [Pharmacokinetics and tolerance of ceftriaxone after subcutaneous administration]. Pathol Biol (Paris) 36: 702-705. [Crossref]
25. Coviaux MF, Hary L, Hurtel AS, Andrejak M, Grumbach Y (2000) etude pharmacoclinique comparative de la ceftriaxone par voie sous-cutanée et intraveineuse chez la personne âgée. Rev Geriatr 25: 337-347.

26. Lacut JY, Dupon M, Quentin C, Brachet-Liermain A, Granger C, et al. (1986) [Clinical evaluation of ceftriaxone in severe infections in adults]. Pathol Biol (Paris) 34: 451456. [Crossref].

27. Rocephine $1 \mathrm{~g} / 3,5 \mathrm{ml}$, poudre et solvant pour solution injectable (IM, SC). Résumé des caractéristiques du produit. [Internet]. France. Agence nationale de sécurité du médicament et des produits de santé (ANSM). [Cited 2013 Jan 30].

28. Agencia Española del Medicamento y Productos Sanitarios. Ficha técnica de Maxipime ${ }^{\circledR}$ Cefepima diclorhidrato monohidrato $500 \mathrm{mg}, 1 \mathrm{~g}, 2 \mathrm{~g}$, polvo para solución inyectable. [Internet]. Madrid: AEMPS, Ministerio de Sanidad y Política Social [Cited 2013 May 13]. Available from: http://www.aemps.gob.es/cima/pdfs/es/ft/60545/FT60545.pdf.

29. Champoux N, Du Souich P, Ravaoarinoro M, Phaneuf D, Latour J, et al. (1996) Singledose pharmacokinetics of ampicillin and tobramycin administered by hypodermoclysis in young and older healthy volunteers. Br J Clin Pharmacol 42: 325-331. [Crossref]

30. Robelet A, Caruba T, Corvol A, Bégué D, Gisselbrecht M, et al. (2009) [Antibiotics given subcutaneously to elderly]. Presse Med 38: 366-376. [Crossref]

31. Amikacine $500 \mathrm{mg} / 4 \mathrm{ml}$, solution injectable. Résumé des caractéristiques du produit [Internet]. France. Agence nationale de sécurité du médicament et des produits de santé (ANSM). [Cited 2013 Jan 30]. Available from http://agence-prd.ansm.sante.fr/php/ ecodex/frames.php?specid=63629234\&typedoc=R\&ref $\% 20=\mathrm{R} 0147581$.

32. Guide de reconstitution et d'administration des principaux Anti-infectieux injectable. [Internet]. France. Agence nationale de sécurité du médicament et des produits de santé (ANSM). [Cited 2013 Jun 30]. Available from: http://www.omedit-centre.fr/ fichiers/upload/Guide_Reconstitution-et-administration_Anti-infectieux-injectables Fevrier-2013.pdf.

33. Barbot A, Venisse N, Rayeh F, Bouquet S, Debaene B, et al. (2003) Pharmacokinetics and pharmacodynamics of sequential intravenous and subcutaneous teicoplanin in critically ill patients without vasopressors. Intensive Care Med 29: 1528-1534. [Crossref]

Copyright: (C2017 Gallardo R. This is an open-access article distributed under the terms of the Creative Commons Attribution License, which permits unrestricted use, distribution, and reproduction in any medium, provided the original author and source are credited. 